\title{
Organizational Values Scale: Development, Validity and Reliability Study
}

\author{
Güneş AKHAN ÇAĞIRTEKİN*1 (D) Cemal AKÜZÜM² \\ ${ }^{1}$ Dicle University, Institute of Educational Sciences, Diyarbakır, Turkey, gunesakhan@gmail.com \\ 2 Dicle University, Faculty of Education, Diyarbakır, Turkey, cemal.akuzum@dicle.edu.tr \\ * Corresponding Author: cemal.akuzum@dicle.edu.tr
}

Article Info

Received: 28 May 2020

Accepted: 22 September 2020

Keywords: Value, organizational values, organizational values scale.

DOI: $10.18009 /$ jcer.744593

Publication Language: English

\begin{abstract}
With globalization, the changes in societies have affected organizations and brought the "human" factor to the fore. Since educational institutions are human oriented organizations, values have become an indispensable element of schools. Therefore, it is thought that determining teachers' perceptions of organizational values will be useful in related researches. The aim of this study is to develop a scale that allows teachers to measure their perceptions of organizational values. The study sample was composed of 49 items and 232 teachers working in secondary schools. After performing Explanatory Factor Analysis, 5 sub-scales and 43 items were obtained. The total variance of the scale was explained by $60.683 \%$. The total Alpha rate of the scale was found to be .946 . The structure of the scale, revealed by Explanatory Factor Analysis, was confirmed by Confirmatory Factor Analysis. It can be said that the scale is a valid and reliable data collection tool.
\end{abstract}

To cite this article: Akhan-Çağırtekin, G. \& Aküzüm, C. (2020). Organizational values: Development, validity and reliability study. Journal of Computer and Education Research, 8 (16), 672-687. DOI: $10.18009 /$ jcer.744593

\section{Introduction}

In the competitive environment created by the rapid changes that are the product of globalization, removing the boundary in many areas, it has become compulsory for organizations to use their resource in the best way to survive. The most important part of these sources is the "human" factor (Gümüş \& Sezgin, 2012: 79-82). Such a resource provides an undeniable benefit to the organizations in competitive environments within the framework of today's understanding (Aycan, Kanungo \& Mendonça, 2016: 87). In addition, it is important to adopt manpower in the organization in achieving success (Güney, 2015: 280281). Because as long as people continue to work together, organizations continue their existence (Mcshane \& Glinow, 2016: 5). The survival of organizations and individuals is achieved by values (Kılıç, 2010: 86). Values enable individuals in organizations to work together in a relaxed and peaceful manner (Mcshane \& Glinow, 2016: 36). 
Values lead to the goals of individuals in the individual dimension and the goals of organizations in the organizational dimension. Organizational values that are compatible with the values of individuals are more easily adopted by employees (Vurgun \& Öztop, 2011: 217). Values shared by employees in organizations, adopted by the organization and guiding the behavior of employees are defined as organizational values (Sığrl, 2007). It is important to adopt organizational values in order to motivate employees in an organization, create and efficient environment and make the organization successful (Vurgun \& Öztop, 2011: 218). When employees in an organization adopt the core values of the organization, in other words, share the same values, internal integration is expected to occur in the organization. It is also thought that employees will share the necessary mental processes for organizations (Sağnak, 2004: 87). Organizational values enable organizations to act for common purposes, manage the work in the organization, provide effective communication and motivate the employees in the organization (Turan, Durceylan \& Şişman, 2005: 184).

Recently, the issue of organizational values has become very popular and many academic studies have been carried out on this subject (Rokeach, 1979; Schwartz, 1994; Finegan, 2000; Kuşdil \& Kağıtçıbaşı, 2000; Hofstede, 2001; Sezgin, 2006; Battal, 2007; Sığrı, 2007; Fitzgerald \& Desjardins, 2004; Posner, 2010; Garza \& Morgeson, 2012; Özcan, 2012; Vvinhardt \& Gulbovaite, 2017). In the studies, the subject of organizational values is classified in different ways. In his studies on values, Allport and his colleagues classified the values, existing in organizational life, into 6 groups: Theoretical values, political values, social values, aesthetic values, economical values and religious values. Theoretical Values give importance to using a rational method to find the existing facts. Political Values emphasize the reach of power and its importance. Social Values defend the idea that one of the most important value is to love other people. Aesthetic Values are related to form and harmony. Economical Values indicate that it is important to be useful and functional. Religious Values defend that people's thoughts, understandings and everything should be combined and integrated (cited by Özkalp \& Kırel, 2013: 109, 110). Rokeach (1979) classified the values as Terminal Values and Instrumental Values. Terminal values can be expressed as equality, inner harmony and family security. Instrumental values are being honest, brave, imaginative, independent, rational and helpful. Some of these values can be shared with other organizations (Rokeach, 1979: 263). Schwartz divided values into ten groups, making them a circle-shaped sequence (Keskin, 2016: 52). These groups are power, security, conformity, 
tradition, benevolence, universalism, self-direction, stimulation, hedonism and achievement (Schwartz, 1994: 22). This theory of values shaped to define active relationships between the mentioned value groups (Kuşdil \& Kağıtçıbaşı, 2000: 62). Hofstede (2001) divided the values into five groups: Masculinity-Femininity, Individualism-Collectivism, Power Distance, Short TermLong Term Orientation and Uncertainty Avoidance. In this study, as the research is carried out on the basis of Hofstede's (2001) cultural value dimensions, the explanations for each dimension in the classification are given below:

a) Masculinity-Femininity is concerned with the distinction of emotional roles between women and men (Hofstede, 2001: 29). If values such as ambition, freedom, power, aggression and domination are dominant in an organization, a division of labor has been made according to masculine values in these organizations (Şişman, 2011: 60). Masculinity values emphasize being ambitious, money and materialism rather than the quality of life and the needs of others. Life is seen as a competition; individuals try to be superior by using force if necessary, it is important to be best and fastest (Hofstede, Pederson and Hofstede, 2002: 116). Organizations where femininity values are dominant do not have high levels of work stress (Güney, 2015: 201). Human relationships are more important in these organizations than competition (Mschane \& Glinow, 2016: 42).

b) Individualism-Collectivism is related to the integration of individuals in organizations (Hofstede, 2001: 29). In the organizations where the individualism is at the forefront, employees are more autonomous (Sar1, 2017: 252) and personal interests are prioritized (Şişman, 2011: 61). In collectivism people act as part of their organization (Robbins and Judge, 2017: 153). Collectivism is the value dimension in which people have strong commitment to their organizations and have loyalty to their organizations without questioning (Kağıtçıbaşı and Cemalcılar, 2015: 322).

c) Power Distance is related to different solutions to human inequality in organizations (Hofstede, 2001: 29). Robbins and Judge (2017) reported the power distance as a way of perceiving that the force distributed in organizations and communities are not equal. In organizations with low power distances, managers and employees communicate with each other more easily. When managers make decisions they get opinions of the employees. Employees behave in a way that focuses on human values (Güney, 2015: 199). Employees obey authority in organizations where the distance of power high (Mcshane \& Glinow, 2016: $41,42)$. 
d) Short Term-Long Term Orientation is related to people's focus on the future or the present (Hofstede, 2001: 29). In short term oriented organizations, traditions are unquestionably important. A lot of time is spent on social rituals. It is very important to live the moment and get fast results. In long term oriented organizations individuals work extremely hard, it is important to be profitable, not to be happy (Hofstede, Pederson \& Hofstede, 2002: 156, 158).

e) Uncertainty Avoidance is related to the level of stress of society when faced with an unknown situation (Hofstede, 2001: 29). In organizations where the level of uncertainty avoidance is low, anxiety and stress levels are low. These organizations are open to innovations and changes. Individuals do not avoid breaking the rules when they need them (Doğan, 2013: 27). In organizations where the level of uncertainty avoidance is high, the working environment is formal. The rules are clear and decisions are documented in writing. Communication in these organizations is clear (Mschane \& Glinow, 2016: 42). People worry about uncertain behaviors and use rules and control system to reduce this uncertainty (Robbins \& Judge, 2017: 153).

Organizational values, which are effective in ensuring the continuity of societies and organizations, also play an important role in schools, work together and communicate effectively together is achieved through organizational values in schools (Ulusoy \& Dilmaç, 2016: 57). Teachers' strong communication with their colleagues is one of the factors that are effective in the success of teachers (Taşdan \& Erdem, 2010: 94). Therefore, it is thought that the negative perceptions of teachers towards organizational values reduce teachers' performance. In order to solve this problem, teachers need to be aware of their own perceptions of organizational values. The aim of this study is to develop a scale to develop a scale to determine teachers' perceptions of organizational values that have become important in educational life as well as in organizational life today. For this purpose, a five-point Likert-type “Organizational Values Scale” was developed to determine teachers' perceptions of organizational values. Many measurement tools have been developed to measure organizational values (Battal, 2007; Yoo, Dontho \& Lenartowicz, 2011; Devaney, 2012; Vvinhardt \& Guldovaite, 2017). However, few studies have been done to test the factor structures of the scale (Hofstede, 2001) mentioned in the literature (Battal, 2007). In this context, it is aimed to raise awareness of these dimensions. Therefore, it is thought that the 
scale of organizational values will contribute to the literature. The results of the research are expected to contribute to training of teachers and their professional development.

\section{Method}

This research was carried out to determine validity and reliability study of the scale. Study Group

In the development of the organizational values scale, the participants of the research consisted of 232 teachers working in different secondary schools located in the center of Ergani district of Diyarbakır province. Of the 232 participants, 95 (40\%) were female and 137 (59\%) were male. Of the 232 participants, 169 (\%72) were married and 63 (\%27) were single. Of the 232 participants, 69 (29\%) were aged 30 or younger, 127 (54\%) were aged 31-40 and 36 (15\%) were aged 41 or older. Of the 232 participants, 129 (55\%) graduated from the faculty of education, $40(17 \%)$ from the faculty of science and literature and 63 (27\%) from other faculties. Of the 232 participants, 33 (14\%) had 0-25 teachers in their schools, 171 (73\%) had 26-50 teachers in their schools and $28(12 \%)$ had 51 and over teachers in their schools.

Scale

The Organizational Values Scale was developed based on Hofstede's (2001) cultural value dimensions. This model includes 5 basic dimensions. These dimensions are "Masculinity-Femininity", "Individualism-Collectivism", "Power Distance", "Short Term-Long Term Orientation" and "Uncertainty Avoidance". In order to develop the organizational values scale, in the item pool preparation process, a detailed literature review was made about the scale and similar measurement tools were examined (Hofstede, 2001; Battal, 2007; Yoo, Dontho \& Lenatowicz, 2011; Devaney, 2012; Vvinhardt \& Guldovaite, 2017). As a result of the review, an item pool containing 100 items were created. The number of items in the item pool was reduced to 80 by removing similar and repeating expressions in these items. Before the pre-application of the scale, 6 language specialists, working in the school where the researcher worked, were consulted to determine the comprehensiveness and the suitability of grammar in the scale. In addition, 6 experts from the field of educational science have been consulted to examine the face validity and content validity of the scale. Based on expert opinions, 31 items were deleted from 80-item pool and 49 items were included in the scale before application. A 5-point Likert-type rating was selected for the level of participation of the item pool and rated as "Strongly agree" (5), "Agree" (4), “Undecided" (3), “Disagree" (2) 
and "Strongly disagree" (1). After these processes, validity and reliability studies were started.

\section{Research Process}

In order to determine to what extent the items in the scale measure the properties to be measured, construct validity and reliability studies have been carried out. The construct validity of the scale was first examined with Exploratory Factor Analysis (EFA) and Confirmatory Factor Analysis (CFA) was applied to verify this construction. In order to determine the validity and reliability level of the scale, the scale was pre-applied to 240 teachers, who were selected objectively, before the sample group and 232 of the scales were evaluated. 8 of these scales have been excluded from the study because demographic information is not filled out or a single participation degree marked. Therefore, a total of 232 teachers' data were processed. Firstly, EFA and CFA were done over the same data set. In addition, the relationship between the factors that make up the scale was also examined SPSS and AMOS programs are used for EFA and correlation.

\section{Findings}

In this section, the validity and reliability studies of the organizational values are included.

Findings for Exploratory Factor Analysis

Exploratory Factor Analysis (EFA) was carried out with 49 items in the organizational values scale. The adequacy of the sample was examined using Kaiser-Meyer-Olkin (KMO) value in EFA and the suitability of data for factor analysis using Barlett's test of Sphericity. KMO value was found to be .915 and Barlett test revealed a statistically significant difference $\left(\chi^{2}=5835.809, p=.000\right)$. After the analysis studies, six items $(9,13,29,31,42$ and 46) with load values below .30 and loading difference less than .10 have been deleted. In addition, three items in the final version of the scale $(19,20$, and 21$)$ were taken as reversed items to the scale. As a result of these values, it was concluded that EFA can be performed with the data. 43 items of the scale were taken into principal component analysis with five factors and varimax (25) rotation was performed. As a result of EFA, the scale was formed in 43 items and five-factor structure. The scree-plot graph for the scale also provides evidence for the five-factor structure of the scale. The scree-plot graph of the scale is included in figure 1. 


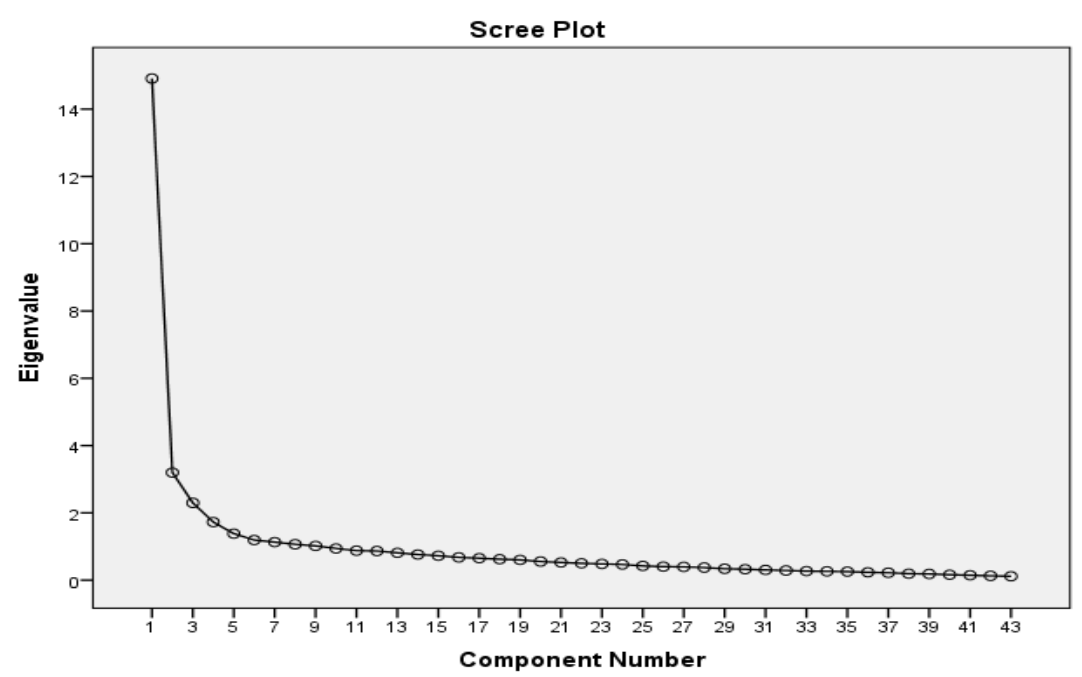

Figure 1. Scree-plot graph of the scale

The first factor of the scale was named as "Masculinity-Femininity", the second factor as "Individualism-Collectivism", the third factor as "Power Distance", the fourth factor "Short Term-Long Term Orientation" and the fifth factor as "Uncertainty Avoidance". The first factor of the scale was "Masculinity-Femininity", which explained $11.48 \%$ of the variance and consisted of 8 items. Its item total correlations varied between .855 and .503 . The second factor of the scale was "Individualism-Collectivism", which explained $13.98 \%$ of the variance and consisted of 10 items. Its item total correlations varied between .851 and .447. The third factor of the scale was "Power Distance", which explained $13.24 \%$ of the variance and consisted of 8 items. Its item total correlations varied between .865 and .711 . The fourth factor of the scale was "Short Term-Long Term Orientation", which explained $10.45 \%$ of the variance and consisted of 9 items. Its item total correlations varied between .839 and .484. The fifth and the final factor of the scale was "Uncertainty Avoidance", which explained $10.50 \%$ of the variance and consisted of 8 items. Its item total correlations varied between .852 and .629 . The total variance explained by these items on the scale adequately explained the quality measured. As a result, the scale was obtained in a five-factor structure with 43 items. Table 1 can be examined for the EFA's findings 
Table 1. Organizational Values scale EFA results Table and Cronbach-Alpha Coefficients

\begin{tabular}{|c|c|c|c|c|}
\hline Factor Name & $\begin{array}{l}\text { Number } \\
\text { of Items }\end{array}$ & $\begin{array}{l}\text { Factor } \\
\text { Loading }\end{array}$ & $\begin{array}{c}\text { Variance } \\
\text { Explained } \\
(\%)\end{array}$ & $\begin{array}{c}\text { Reliability } \\
\text { Coefficient } \\
\text { (Cronbach's } \\
\text { Alpha) }\end{array}$ \\
\hline \multirow{8}{*}{ Masculinity-Femininity } & 1 & .855 & \multirow{8}{*}{11.486} & \multirow{8}{*}{.826} \\
\hline & 2 & .822 & & \\
\hline & 3 & .599 & & \\
\hline & 4 & .503 & & \\
\hline & 5 & .761 & & \\
\hline & 6 & .847 & & \\
\hline & 7 & .847 & & \\
\hline & 8 & .633 & & \\
\hline \multirow{10}{*}{ Individualism-Collectivism } & 9 & .851 & \multirow{10}{*}{13.989} & \multirow{10}{*}{.872} \\
\hline & 10 & .798 & & \\
\hline & 11 & .677 & & \\
\hline & 12 & .447 & & \\
\hline & 13 & .623 & & \\
\hline & 14 & .687 & & \\
\hline & 15 & .732 & & \\
\hline & 16 & .812 & & \\
\hline & 17 & .765 & & \\
\hline & 18 & .693 & & \\
\hline \multirow{8}{*}{ Power Distance } & 19 & .730 & \multirow{8}{*}{13.249} & \multirow{8}{*}{.824} \\
\hline & 20 & .711 & & \\
\hline & 21 & .797 & & \\
\hline & 22 & .780 & & \\
\hline & 23 & .847 & & \\
\hline & 24 & .865 & & \\
\hline & 25 & .780 & & \\
\hline & 26 & .842 & & \\
\hline \multirow{9}{*}{$\begin{array}{l}\text { Short Term-Long Term } \\
\text { Orientation }\end{array}$} & 27 & .648 & \multirow{9}{*}{10.458} & \multirow{9}{*}{.872} \\
\hline & 28 & .641 & & \\
\hline & 29 & .664 & & \\
\hline & 30 & .484 & & \\
\hline & 31 & .782 & & \\
\hline & 32 & .775 & & \\
\hline & 33 & .839 & & \\
\hline & 34 & .710 & & \\
\hline & 35 & .784 & & \\
\hline \multirow{8}{*}{ Uncertainty Avoidance } & 36 & .767 & \multirow{8}{*}{10.501} & \multirow{8}{*}{.828} \\
\hline & 37 & .664 & & \\
\hline & 38 & 651 & & \\
\hline & 39 & .772 & & \\
\hline & 40 & .629 & & \\
\hline & 41 & .694 & & \\
\hline & 42 & .771 & & \\
\hline & 43 & .852 & & \\
\hline
\end{tabular}

Total Variance Explained $=60.683$

Kaiser-Meyer-Olkin of Sampling Adequacy $(K M O)=.915$

Barlett's Test of Sphericity Chi-Squared $=5835.809$

$s d=903$

$p=.000$

Total Cronbach's Alpha $=.946$ 
Findings for Confirmatory Factor Analysis

Confirmatory factor analysis (CFA) is testing to verify the relationship between previously determined items (Büyüköztürk, 2017: 134; Ünal, 2014: 25). In CFA, a state diagram is used to determine variables that are thought to be associated with factors of the scale. Through this state diagram, relations between factors and variables are determined (Schumacker and Lomax 1996; cited by Çokluk, Şekercioğlu and Büyüköztürk, 2016: 260). CFA measured the latent factors in the structure of the scale and their mutually dependent effects among these factors. As a result of analysis, it indicates the one-way linear relationship. This shows how well each item of the scale represents latent variables (Huck, 2012: 518). The compliance criteria in Figure 2 shows that the level of compliance of the five factor modal obtained from CFA is acceptable and adequate.

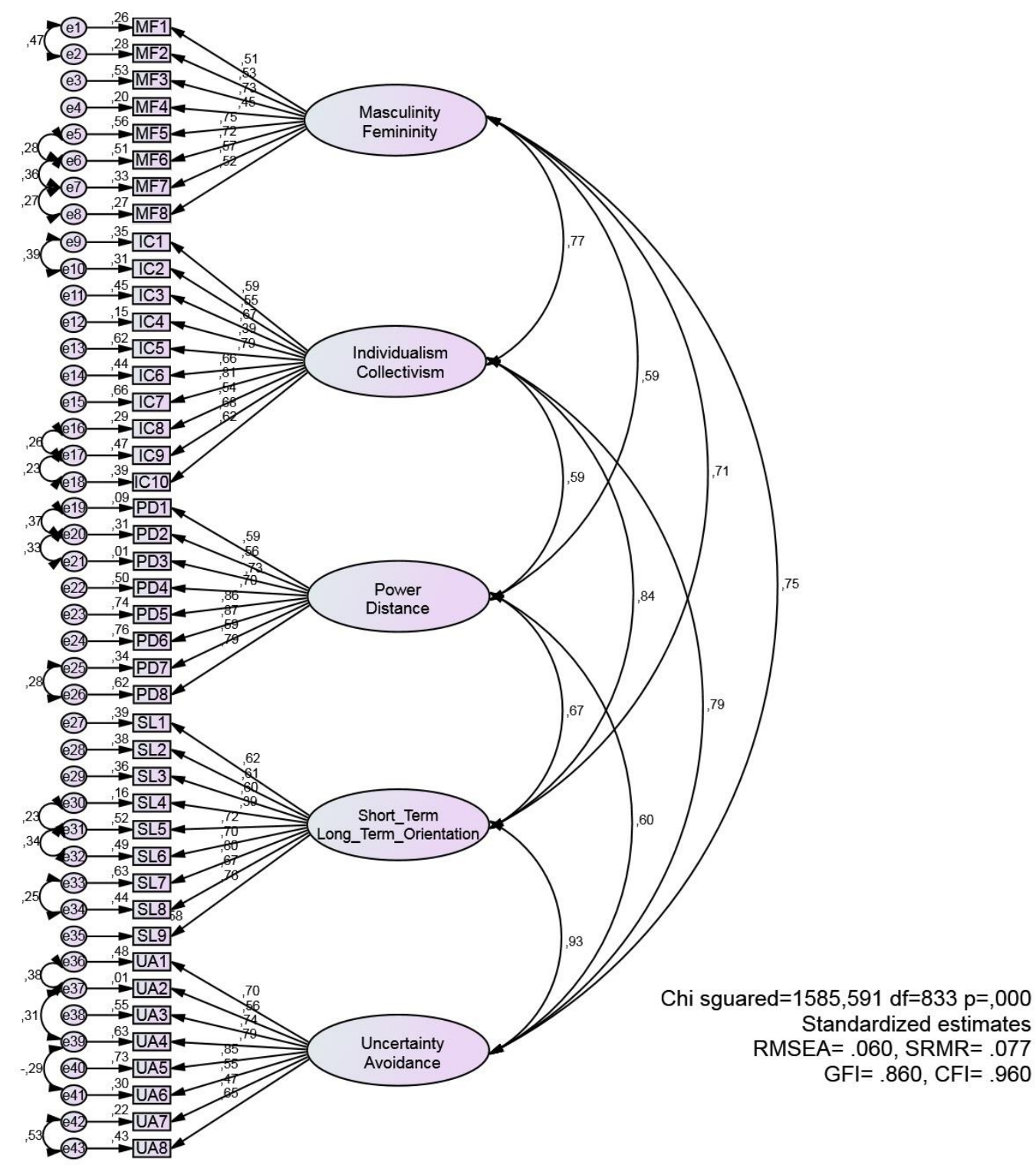

Figure 2. Confirmatory factor analysis diagram of data collection tool 
The structure of the organizational values scale consisting of 43 items and five factors was tested through CFA. Firstly the fit indices of the model consisting of 43 items and 5 factors were examined with CFA, it has been found that "Masculinity-Femininity" factor has $51, .53, .73, .45, .75, .72, .57$ and .52 standardized solution, respectively; "IndividualismCollectivism" factor has .59, .55, .67, .39, .79, .66, .81, .54, .68 and .62 standardized solution, respectively; "Power Distance" factor has .59, .56, .73, .70, .86, .87, .59 and .79 standardized solution, respectively; "Short Term-Long Term Orientation" factor has .62, .61, .60, .39, .72, $.70, .80, .67$ and .76 standardized solution, respectively and "Uncertainty Avoidance" factor has $.70, .56, .74, .79, .85, .55, .47$ and .65 standardized solution, respectively. The values required for a model to be compatible as follows: CFI $>90$, RMSA<.10; SRMR<.080; GFI $>0.90$ (Yen, Yang, Wu, Hsu and Cheng, 2010; cited by Huck, 2012: 498,520). In addition to these standardized values, GFI values should be higher than .85 . This indicates that the model is compatible with data (Cole, 1987; cited by Ünal, 2014: 26). As a result of the factor analysis of the organizational values scale; RMSEA: .060; Chi squared: 1585, 591; df: 833; p: ,000; SRMR: .077; GFI: .860; CFI was found as .960. When the findings were examined chi squared $\left(\chi^{2}\right)$ value was found as 1585,591 and $\mathrm{df}$ (sd) value was found as 83 . When we compare these values, the ratio of $\chi^{2} / \mathrm{sd}$ is $1,90(1585,591 / 833: 1,90)$. The ratio of $\chi^{2} / \mathrm{sd}<3$ means that the fit of the model is perfect (Çokluk, Şekercioğlu \& Büyüköztürk, 2016: 315). These findings show that the scale's fit index value is at the desired level and the scale provides the required construct validity (Huck, 2012: 498).

\section{Reliability Findings}

For 43 items of the organizational values scale, Cronbach Alpha coefficient was found to be .946 and items' factor load values varied between .449 and .865 . The Cronbach Alpha coefficient of "Masculinity-Femininity" factor was .826; "Individualism-Collectivism" factor was .872; "Power Distance" factor was .824; "Short Term-Long Term Orientation" factor was .872 and "Uncertainty Avoidance" factor was .828. Since the Cronbach Alpha coefficient obtained from scale analysis is over .70, the scale has adequate reliability (Büyüköztürk, 2017: 183). 


\section{Discussion and Conclusions}

With changing social conditions, the basic element in the organizations has become individuals. Values, which have become popular in recent times, are one of the factors that are effective in shaping the behavior of individuals. It is thought that organizational values of educational organizations provide effective communication between teachers and support the performance of the teachers. Since teachers have a critical role in educational organizations, the scientific determination of teachers' perceptions about organizational values is important for educational research. This study was carried out to develop the scale of organizational values. Studies in the literature show that teachers' perceptions of organizational values affect their performance (Kuşdil \& Kağıtçıbaşı, 2000; Sezgin, 2006). In addition, in Polat's (2012) statement, school administrators need to analyze and strengthen the organizational values of teachers in order to guide teachers' behavior.

In this study, a valid and reliable scale was developed to measure teachers' perceptions of organizational values working in secondary schools. The developed scale is a 5-point Likert-type and the scale includes "Masculinity-Femininity", "IndividualismCollectivism", "Power Distance", "Short Term-Long Term Orientation" and "Uncertainty Avoidance" sub dimensions and 43 items to measure teachers' perceptions of organizational values. As a result of this study, the scale was found to have significant psychometric properties. The "Organizational Values Scale" is a measurement tools consisting of five subdimensions. There are 8 items in the sub-dimension of "Masculinity-Femininity", 10 items in the sub-dimension of "Individualism-Collectivism", 8 items in the sub-dimension of "Power Distance", 9 items in the sub-dimension of "Short Term-Long Term Orientation" and 8 items in the sub-dimension of "Uncertainty Avoidance". Factor correlation values of the scale have been calculated to determine what extent the items on the scale measure the desired properties. The Alpha reliability coefficient for the sub-dimensions of the scale is sufficient (Masculinity-Femininity $=.826$, Individualism-Collectivism $=.872$, Power Distance $=.824$, Short Term-Long Term Orientation $=.872$, Uncertainty Avoidance $=.828$ ). And it shows that the items are consistent with each other. The results of Exploratory Factor Analysis and Confirmatory Factor Analysis also confirmed the validity of the scale. The findings obtained from the study show that the scale has valid and appropriate qualifications in determining the perceptions of teachers working in secondary schools about organizational values. 
It is important to mention some limitations of this study. Participants were selected from secondary schools in Diyarbakır. For the generalization of the research findings, the scale can also be applied in different provinces and schools with different educational levels. In addition, the scale can be examined in different demographic variables in secondary schools across the country and the results of the research can be compared.

Acknowledgement

The data used in this study was confirmed by the researchers that it belongs to the years before 2020.

Authorship Contribution Statement

Güneş AKHAN ÇAĞIRTEKİN: Design and development, methodology, data curation, formal analysis, writing-original draft

Cemal AKÜZÜM: Conceptualization, methodology, supervision, writing-original draft, writing-review \& editing

\section{References}

Aycan, Z., Kanungo, R. N. \& Mendonça, M. (2016). Örgütler ve yönetim [Organizations and management]. İstanbul: Koç Üniversitesi Yayınları.

Battal, A. (2007). Örgütsel değerlerin örgüt kültürü ögelerine etkisi [Effect of organizational values on organization culture elements]. Yayınlanmamış yüksek lisans tezi. Dumlupınar Üniversitesi, Sosyal Bilimler Enstitüsü, Kütahya.

Büyüköztürk, Ş. (2017). Sosyal bilimler için veri analizi el kitabı [Data analysis handbook for social sciences]. Ankara: PegemA Yayıncilık.

Çokluk, Ö., Şekercioğlu, G. \& Büyüköztürk, Ş. (2016). Sosyal bilimler için çok değişkenli istatistik SPSS ve LISREL uygulamaları [Multivariate statistical SPSS and LISLER applications for social sciences]. Ankara: PegemA Yayıncilık.

Devaney, T. (2012). The revised school culture elements questionnaire. Research in the Schools, 19(2), 30-44.

Doğan, E. Ş. (2013). Örgüt kültürü ve örgütsel bağhllık [Organizational culture and organizational commitment]. İstanbul: Türkmen Kitabevi.

Finegan, J. E. (2000). The impact of person and organizational values on organizational commitment. Journal of Occupational and Organizational Psychology, (73), 149-169.

Fitzgerald, G. A. \& Desjardins, N. M. (2004). Organizational values and their relation to organizational performance outcomes. Atlantic Journal of Communication, 12(3), 121-145.

Garza, A. S. \& Morgeson, F. P. (2012). Exploring the link between organizational values and human resource certification. Human Resource Management Review, 22(4), 271-278.

Gümüş, S. \& Sezgin, B. (2012). Motivasyonun örgütsel bağhllı̆̆a ve performansa etkisi [The effect of motivation on organizational commitment and performance]. İstanbul: Hiperlink. 
Güney, S. (2015). Örgütsel davranış [Organizational behaviour]. Ankara: Pegem Akademi.

Hofstede, G. (2001). Cultural consequences. California: Sage Publication.

Hofstede, G. J. Pederson, P. B. \& Hofstede, G. (2002). Exploring culture. America: Intercultural Press.

Huck, S. W. (2012). Reading statistics and research. America: Pearson Education, Inc. Publishing.

Kağıtçıbaşı, Ç. \& Cemalcılar, Z. (2015). Dünden bugüne insan ve insanlar. Sosyal psikolojiye giriş [Man and people. Introduction to social psychology]. İstanbul: Evrim Kitap.

Keskin, Y. (2016). Değerlere Genel Bir Bakış: Tanımı, Özellikleri, İşlevi ve Sınıflandırılması. Teoriden pratiğe değerler eğitimi [Values education from theory to practice]. (Editör: Mustafa Köylü). Ankara: Nobel Akademik Yayıncllık.

Kılıç, M. (2010). Stratejik yönetim sürecinde değerler, vizyon ve misyon kavramları arasındaki ilişki [Relations between values, mission and vision concepts in strategic management process]. Sosyo Ekonomi Dergisi, (2), 82-98.

Kuşdil, M. E. \& Kağıtçıbaşı, Ç. (2000). Türk öğretmenlerin değer yönelimleri ve Schwartz değer kuramı [Value orientations of Turkish teachers and Schwartz's theory of values running head]. Türk Psikoloji Dergisi, 15(45), 59-76.

Mcshane, S. L. \& Glinow, M. A. V. (2016a). "Örgütsel davranış alanına giriş". (Çev: Esra Alnıaçı). Örgütsel davranış [Organizatonal behavior]. (Çeviri Editörleri: Ayşe Günsel ve Serdar Bozkurt). Ankara: Nobel Akademik Yayıncılık.

Mcshane, S. L. \& Glinow, M. A. V. (2016b). "Bireysel Davranış, Kişilik ve Değerler". (Çeviren: Özge Mehtap). Örgütsel davranış [Organizatonal behavior]. (Çeviri Editörleri: Ayşe Günsel ve Serdar Bozkurt). Ankara: Nobel Akademik Yayıncılık.

Özcan, H. U. (2012). Birey-örgüt değerleri arasındaki uyumun örgütle özdeşleşme ile ilişkisi [The effects of person-organization value fit on organizational identification]. Türk Psikoloji Yazıları, 15(29), 25-39.

Özkalp, E. \& Kırel, Ç. (2013). Örgütsel davranış [Organizatonal behavior]. Bursa: Ekin Basım Yayın Dağıtım.

Polat, S. (2012). Organizational values. Needen for diversity management. Educational Sciences: Theory \& Practice, 2(12), 1409-1418.

Posner, B. Z. (2010). Another look at the impact of personal and organizational values congruency. Journal of Business Ethics, 97(4), 535-541.

Robbins, S. P. \& Judge, T. A. (2017). “Kişilik ve değerler (Çev: Melek Tüz). Örgütsel davranış [Organizatonal behavior]. (Çeviri Editörü: İnci Erdem). Ankara: Nobel Akademik Yayıncilik.

Rokeach, M. (1979). Understanding human values. New York: The Free Press.

Sağnak, M. (2004). Örgütlerde değerler yönünden birey örgüt uyumu ve sonuçları [Value congruence and results in organizations]. Educational Administration in Theory $\mathcal{E}$ Practice, 10(1), 72-95. 
Sarı, E. (2017). Kültürel değerler ve psikolojik iyilik. İş ahlakı ve değerler eğitimi [Business ethics and values education]. (Editör: Mustafa Çakmak). Ankara: PegemA Yayıncilik.

Schwartz, S. H. (1994). Are there universal aspects in structure and contents of human values? Journal of Social Issues, 50(4), 19-45.

Sezgin, F. (2006). Illköğretim okulu öğretmenlerinin bireysel ve örgütsel değerlerin uyumu [Individual and organizational value congruence of elementary school teachers]. Yayınlanmamış doktora tezi. Gazi Üniversitesi, Eğitim Bilimleri Enstitüsü, Ankara.

Sığrı, Ü. (2007). Kamu ve özel sektördeki kişisel ve örgütsel değerlerin uyumlaştırılması üzerine karşılaştırmalı bir çalışma [A comparative study on harmonization of individual and organizational values in government and private sectors]. Muğla Üniversitesi Sosyal Bilimler Enstitüsü Dergisi,(18).

Şişman, M. (2011). Örgütler ve kültürler [Organizations and cultures]. Ankara: Pegem Akademi.

Taşdan, M. \& Erdem, M. (2010). İlköğretim okulu öğretmenlerinin iş yaşam kalitesi ile örgütsel değer algıları arasındaki ilişki düzeyi [Quality of work life and its relation to organizational value according to teachers persection in elementary schools] . Yüzüncü Yıl Üniversitesi, Ĕ̆itim Fakültesi Dergisi, 7(11), 92-113.

Turan, S., Durceylan, B. \& Şişman, M. (2005). Üniversite yöneticilerinin benimsedikleri idari ve kültürel değerler [The management and cultural values that university administrators appreciate]. Manas Üniversitesi Sosyal Bilimler Dergisi, 7(13), 181-202.

Ulusoy, K. \& Dilmaç, B. (2016). Değerler eğitimi [Values education]. Ankara: PegemA Yayıncilik.

Ünal, A. (2014). Örgütsel öğrenme mekanizmalarının okullarda kullanılması konusunda öğretmen görüşleri [The opinions of teachers about use of organizational learning mechanisms in schools]. Pamukkale Üniversitesi Ĕ̆itim Fakültesi Dergisi, (35), 19-32.

Vurgun, L. \& Öztop, S. (2011). Yönetim ve örgüt kültüründe değerlerin önemi [Significance of values for management and organizational culture]. Süleyman Demirel Üniversitesi İktisadi ve İdari Bilimler Fakültesi Dergisi, 16(3), 217-230.

Vvinhardt, J. \& Gulbovaite, E. (2017). Reability of Methodological and psychometric characteristics of the questionnaire of congruance of personal and organizational values. Oeconomia Copernicana, 9(3), 545-571. 
APPENDIX 1- Organizational Values Scale

\begin{tabular}{|c|c|c|c|c|c|c|}
\hline 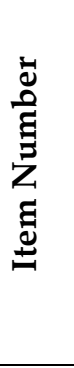 & $\begin{array}{l}\text { Dear participant, } \\
\text { Please indicate your level of agreement with the } \\
\text { statements below by checking the appropriate } \\
\text { option for you according to the scoring given } \\
\text { below. } \\
\text { (1=Strongly Disagree, } 2=\text { Disagree, } \\
\text { 3=Neutral, } 4=\text { Agree, } 5=\text { Strongly Agree) }\end{array}$ & 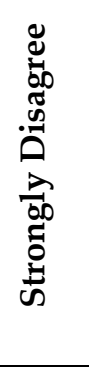 & 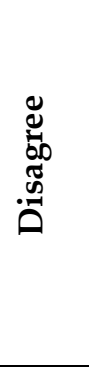 & $\underset{\overparen{\pi}}{\overparen{\pi}}$ & 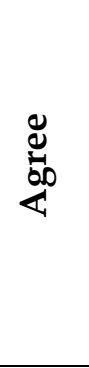 & 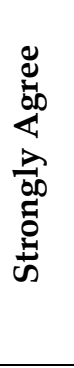 \\
\hline \multicolumn{7}{|c|}{ Masculinity-Femininity } \\
\hline 1 & $\begin{array}{l}\text { In our school, teachers use scientific studies for their } \\
\text { professional development. }\end{array}$ & ( 1 ) & (2) & (3) & (4) & ( 5 ) \\
\hline 2 & $\begin{array}{l}\text { In our school, teachers follow periodicals (articles, } \\
\text { books, magazines, etc.) about their fields. }\end{array}$ & ( 1 ) & (2) & (3) & (4) & $(5)$ \\
\hline 3 & In our school, conflicts are solved through logic. & (1) & (2) & (3) & (4) & (5) \\
\hline 4 & $\begin{array}{l}\text { In our school, there are teachers who can take risks } \\
\text { easily with the ambition to work. }\end{array}$ & ( 1 ) & (2) & (3) & (4) & $(5)$ \\
\hline 5 & In our school, teachers respect each other's ideas. & $(1)$ & $(2)$ & $(3)$ & $(4)$ & $(5)$ \\
\hline 6 & $\begin{array}{l}\text { In our school, teachers help each other in solving } \\
\text { problems. }\end{array}$ & (1) & (2) & (3) & (4) & $(5)$ \\
\hline 7 & $\begin{array}{l}\text { In our school, teachers behave like greeting and } \\
\text { asking after each other. }\end{array}$ & (1) & (2) & (3) & (4) & ( 5 ) \\
\hline 8 & $\begin{array}{l}\text { In our school, It is important to engage in social } \\
\text { activities together like having a picnic, going to } \\
\text { dinner, etc. }\end{array}$ & (1) & (2) & (3) & (4) & ( 5 ) \\
\hline \multicolumn{7}{|c|}{ Individualism-Collectivism } \\
\hline 9 & $\begin{array}{l}\text { In our school, teachers' individual freedom is } \\
\text { important. }\end{array}$ & ( 1 ) & (2) & (3) & (4) & ( 5 ) \\
\hline 10 & $\begin{array}{l}\text { In our school, teachers have a responsibility to decide } \\
\text { individually. }\end{array}$ & ( 1 ) & (2) & (3) & ( 4 ) & ( 5 ) \\
\hline 11 & $\begin{array}{l}\text { In our school, teachers are given tasks which they can } \\
\text { use their abilities. }\end{array}$ & (1) & (2) & (3) & (4) & ( 5 ) \\
\hline 12 & $\begin{array}{l}\text { In our school, teachers' relationships with colleagues } \\
\text { are independent. }\end{array}$ & ( 1 ) & (2) & (3) & (4) & ( 5 ) \\
\hline 13 & In our school common values are prioritized. & $(1)$ & $(2)$ & $(3)$ & $(4)$ & $(5)$ \\
\hline 14 & In our school, everyone is proud of their school. & (1) & $(2)$ & $(3)$ & $(4)$ & $(5)$ \\
\hline 15 & $\begin{array}{l}\text { In our school, teamwork is given importance because } \\
\text { of the consciousness of being us. }\end{array}$ & ( 1 ) & (2) & (3) & (4) & ( 5 ) \\
\hline 16 & $\begin{array}{l}\text { In our school, teachers sacrifice their personal time } \\
\text { for their institutions when necessary. }\end{array}$ & ( 1 ) & (2) & (3) & ( 4 ) & ( 5 ) \\
\hline 17 & $\begin{array}{l}\text { In our school, everyone is more responsible for the } \\
\text { success of the school than individual success. }\end{array}$ & (1) & (2) & (3) & (4) & ( 5 ) \\
\hline 18 & $\begin{array}{l}\text { In our school, teachers spend time together to explore } \\
\text { ways to improve their institutions. }\end{array}$ & ( 1 ) & (2) & (3) & (4) & ( 5 ) \\
\hline \multicolumn{7}{|c|}{$\begin{array}{ll}\text { Power Distance } \\
\end{array}$} \\
\hline 19 & $\begin{array}{l}\text { In our school, superior-subordinate relationships are } \\
\text { very formal. }\end{array}$ & ( 1 ) & (2) & (3) & ( 4 ) & ( 5 ) \\
\hline 20 & $\begin{array}{l}\text { In our school, administrators often use the power } \\
\text { they take from authority in their relationship with } \\
\text { teachers. }\end{array}$ & (1) & (2) & (3) & (4) & (5) \\
\hline
\end{tabular}


Akhan-Çă̆ırtekin $\mathcal{E}$ Aküzüm

\begin{tabular}{|c|c|c|c|c|c|c|}
\hline 21 & $\begin{array}{l}\text { In our school, teachers fulfill their administrators' } \\
\text { request without questioning them. }\end{array}$ & ( 1 ) & (2) & (3) & (4) & ( 5 ) \\
\hline 22 & $\begin{array}{l}\text { In our school, administrators are sympathetic to } \\
\text { teachers. }\end{array}$ & (1) & (2) & (3) & (4) & ( 5 ) \\
\hline 23 & $\begin{array}{l}\text { In our school, teachers easily convey their problems } \\
\text { to their managers. }\end{array}$ & (1) & (2) & (3) & (4) & ( 5 ) \\
\hline 24 & $\begin{array}{l}\text { In our school, administrators sincerely help teachers } \\
\text { in their professional development. }\end{array}$ & (1) & (2) & (3) & (4) & ( 5 ) \\
\hline 25 & $\begin{array}{l}\text { In our school, administrators spend time with } \\
\text { teachers outside of work. }\end{array}$ & (1) & (2) & (3) & (4) & ( 5 ) \\
\hline 26 & $\begin{array}{l}\text { In our school, administrators are open to the } \\
\text { opinions and suggestions of the employees in their } \\
\text { decisions. }\end{array}$ & (1) & (2) & (3) & (4) & (5) \\
\hline \multicolumn{7}{|c|}{$\begin{array}{l}\text { Short Term-Long Term Orientation } \\
\end{array}$} \\
\hline 27 & $\begin{array}{l}\text { The rituals and traditions of our school are respected } \\
\text { by the teachers. }\end{array}$ & (1) & $(2)$ & (3) & (4) & $(5)$ \\
\hline 28 & $\begin{array}{l}\text { In our school, teachers benefit from their past } \\
\text { experiences in solving problems. }\end{array}$ & (1) & $(2)$ & (3) & (4) & $(5)$ \\
\hline 29 & $\begin{array}{l}\text { In our school, it is important to meet the needs } \\
\text { (education, equipment, etc.) urgently. }\end{array}$ & (1) & $(2)$ & (3) & (4) & $(5)$ \\
\hline 30 & $\begin{array}{l}\text { In our school, teachers think it is important to live the } \\
\text { moment. }\end{array}$ & (1) & $(2)$ & (3) & (4) & $(5)$ \\
\hline 31 & $\begin{array}{l}\text { In our school, teachers' services for social } \\
\text { development are given importance. }\end{array}$ & (1) & $(2)$ & ( 3 ) & (4) & $(5)$ \\
\hline 32 & In our school, long term plans are made. & $(1)$ & $(2)$ & $(3)$ & $(4)$ & $(5)$ \\
\hline 33 & $\begin{array}{l}\text { In our school, efforts are made for the future success } \\
\text { of the school. }\end{array}$ & (1) & $(2)$ & (3) & (4) & $(5)$ \\
\hline 34 & In our school, teachers work steadily. & $(1)$ & $(2)$ & $(3)$ & $(4)$ & $(5)$ \\
\hline 35 & In our school, the resources are not wasted. & $(1)$ & $(2)$ & $(3)$ & $(4)$ & $(5)$ \\
\hline \multicolumn{7}{|c|}{$\begin{array}{l}\text { Uncertainty Avoidance } \\
\end{array}$} \\
\hline 36 & In our school, school rules are important. & $(1)$ & $(2)$ & (3) & $(4)$ & $(5)$ \\
\hline 37 & $\begin{array}{l}\text { In our school, administrators often remind to follow } \\
\text { the rules. }\end{array}$ & (1) & $(2)$ & (3) & (4) & (5) \\
\hline 38 & $\begin{array}{l}\text { In our school, teachers are aware of the school's } \\
\text { goals. }\end{array}$ & (1) & (2) & (3) & (4) & (5) \\
\hline 39 & $\begin{array}{l}\text { In our school, education and training activities are } \\
\text { planned and programmed in detail. }\end{array}$ & (1) & (2) & (3) & (4) & ( 5 ) \\
\hline 40 & $\begin{array}{l}\text { In our school, It is important to successfully complete } \\
\text { school related tasks. }\end{array}$ & (1) & (2) & (3) & (4) & (5) \\
\hline 41 & In our school, teachers value their senior colleagues. & (1) & (2) & (3) & (4) & (5) \\
\hline 42 & $\begin{array}{l}\text { In our school, there is a well intentioned approach } \\
\text { towards new teachers. }\end{array}$ & (1) & $(2)$ & (3) & (4) & ( 5 ) \\
\hline 43 & In our school, there is a peaceful environment. & (1) & (2) & (3) & (4) & (5) \\
\hline
\end{tabular}

JCER's Publication Ethics and Publication Malpractice Statement are based, in large part, on the guidelines and standards developed by the Committee on Publication Ethics (COPE). This article is available under Creative Commons CC-BY 4.0 license (https://creativecommons.org/licenses/by/4.0/) 